\title{
НАПИСАННЯ ІСТОРІЇ ПОЛОГІВ ЯК ОДИН ІЗ ВИДІВ САМОСТІЙНОЇ РОБОТИ СТУДЕНТІВ
}

\author{
О. М. Ласитчук \\ ДВНЗ “Івано-Франківський наџіональниймедичний університет”

\section{WRITING THE HISTORY OF CHILDBIRTH AS ONE OF TYPES OF INDEPENDENT WORK OF STUDENTS} \\ O. M. Lasytchuk \\ SHEI “Ivano-Frankivsk National Medical University"
}

\begin{abstract}
У статті розглянуто написання історії пологів як вид самостійної роботи студентів, що с одним із шляхів інтенсифікації навчання, підвищення якості підготовки майбутнього лікаря, особливо в контексті Болонського процесу. Висвітлено методику оформлення історії пологів, проаналізовано типові студентські помилки в процесі виконання роботи.
\end{abstract}

The article adduced writing the history of childbirth, as the type of independent work of students, that is one of the way of intensification of studies, upgrading the preparation of a future doctor, especially in the context of Bolongna process. Method of registration of history of childbirth was reflected, typical student errors in the process of implementation of work were analyzed.

Вступ. Національна система вищої медичної освіти за останні роки зазнала суттєвих реорганізаційних змін, що зумовлено потребою прискореного входження України в коло високорозвинених країн. Світовою федерацією медичної освіти розроблені сучасні стандарти навчання, серед яких - безперервний професійний розвиток, що грунтується на самоосвіті [1]. Основною характеристикою процесу навчання стає процес самостійного поглиблення професійних знань та навичок, який спрямовується в рамках вимог та тенденцій Болонського процесу [2]. Базові професійні знання студенти здобувають згідно з навчальними планами, а саме через лекції, практичні заняття та самостійну роботу, в організації якої значну роль мають консультації викладачів. В навчально-методичній літературі помітна тенденція до скорочення в навчальних планах аудиторних годин і збільшення годин, відведених на самостійну роботу (до $60 \%$ навчального часу) $[3,4]$.

Метою даної статтіє обгрунтування цілей, змісту i завдань в написанні історії пологів, як одного із видів самостійної роботи студентів, котра $є$ по своій суті багатофункціональною. Зокрема, вона сприяє засвоєнню систематизованих знань, формуванню вмінь i навичок, самостійності як риси характеру. В доступній нам літературі нами не знайдено публікацій, які стосуються проблематики написання студентської історії пологів.
Основна частина. В процесі вивчення дисципліни "Акушерство" навчальною програмою передбачена курація вагітної з подальшим написанням навчальної історії пологів. Написання студентської історії пологів передбачає таке:

- розуміння схеми історії пологів;

· вміння працювати з медичною документацією;

- вміння швидко та деонтологічно зважено зібрати анамнез життя, дітородну функцію та особливості перебігу даної вагітності;

- вміння провести загальнотерапевтичне та спеціальне акушерське обстеження вагітної;

- проаналізувати результати лабораторних та інструментальних досліджень;

- встановити та обгрунтувати попередній клінічний діагноз;

- скласти план ведення вагітності та пологів;

· участь у проведенні пологів;

- описати перебіг пологів та післяпологового періоду.

Історію пологів студенти пишуть на четвертому курсі в кінці вивчення змістового модуля 1 “Фізіологічне акушерство”, після того як вивчені такі розділи акушерства, як структура та організація роботи акушерської служби, пологові шляхи жінки, плід як об’ єкт пологів, фізіологія вагітності, діагностика вагітності, методи дослідження вагітних, пологи та післяпологовий період. Слід зауважити, що деякі труднощі при написанні історії пологів виникають у студентів, коли

(C) О. М. Ласитчук 
курована ними вагітна має ускладнений перебіг вагітності, зокрема гестоз чи іншу патологію. В такому разі студент змушений додатково й наперед опрацьовувати навчальну літературу. Курують студенти жінок 3 доношеною вагітністю або на початку пологів.

Викладачами кафедри розроблена схема студентської історії пологів, з якою студенти мають змогу ознайомитись напередодні курації, з'ясувати незрозумілі для себе моменти. Історія пологів досить схожа з медичною документацією пологових стаціонарів (форма 096/о), оскільки майбутні лікарі повинні розуміти, що остання є юридичним документом, який надзвичайно важливий в організації практичної роботи лікаря, та навчитися грамотно заповнювати іiі. Курація проходить під час практичного заняття в акушерському стаціонарі в умовах, максимально наближених до професійної діяльності лікаря. Вагітні жінки - це особлива категорія пацієнтів, які потребують відповідного ставлення до себе, особливих етико-деонтологічних відносин. Тому викладач активно навчає і допомагає студентам встановлювати мовний, візуальний, тактильний контакт з вагітними. Як показує практика, під час курації студенти набувають досвіду спілкування з пацієнтами, намагаються підтримувати й допомогати вагітним, роділлям та породіллям, особливий інтерес має власне сам процес пологів, стан новонародженого.

Обстеження розпочинають 3 опитування і насамперед з'ясовують паспортні дані, з яких особливе значення мають вік жінки, сімейний статус, місце та умови праці. Скарги повинні бути систематизовані та зведені у відповідні групи, деталізовані, викладені стисло, чітко і послідовно з зазначенням часу їх виникнення. Не викликає труднощів у студентів 3' ясування анамнезу життя та спеціального анамнезу, який в акушерстві надзвичайно важливий. Нерідко він торкається інтимних сторін життя, тому для того щоб отримати достатньо повну і точну інформацію, опитування необхідно проводити делікатно і спрямовувати розповідь пацієнтки в потрібному напрямку.

Досить детального опису вимагає репродуктивна (дітородна) функція. Слід з' ясувати, через який проміжок часу від початку статевого життя без застосування контрацепції настала перша вагітність, скільки було всього вагітностей, яким був перебіг кожної вагітності, чим вони закінчились (пологи, артифіційний чи мимовільний аборт), чи не було передчасних пологів, мертвонароджених дітей, чи не помирали діти у ранньому неонатальному періоді, чи не було ускладнень під час та після пологів, які оперативні втручання проводились під час пологів. Кількість живих дітей, стан їхнього здоров’я. Відсутність вагітності протягом року статевого життя свідчить про неплідність, яка може бути проявом недорозвитку жіночих статевих органів, порушення функції яєчників або результатом перенесеного запального процесу. Якщо вагітності настають рідко, часто перериваються, то це вказує на гормональну недостатність. Обов' язково необхідно з'ясувати, чи жінка користується контрацептивами, якими і протягом якого часу. Перебіг даної вагітності в I і II половинах, чи були ускладнення (ранній гестоз, загроза переривання, набряки, підвищення артеріального тиску, анемія). Чи відвідувала вагітна жіночу консультацію, скільки разів, чи проходила психопрофілактичну підготовку. Дата перших рухів плода, очікувана дата пологів.

Об'єктивне обстеження вагітної поділяється на загальне та спеціальне. Загальне дослідження є складовою міждисциплінарної інтеграції і відображає рівень засвоєння та вміння практично застосувати студентами знання, здобуті при вивченні попередніх дисциплін. Огляд вагітної жінки більш об'ємний i здійснюється за такою схемою:

1. Чи відповідає загальний вигляд вагітної іï віку.

2. Ріст. При маленькому зрості жінки частіше діагностується вузький таз, при високому - чоловіча форма таза.

3. Будова тіла. Неправильна будова тіла, викривлення хребта, потовщення реберних кісток, неоднакова довжина ніг, анкілоз суглобів свідчать про перенесений в дитинстві рахіт. В таких випадках можливе звуження таза і його деформація. Вгодованість: ожиріння чи надмірна худорлявість свідчить про порушення обміну речовин.

4. Шкіра. Пігментація шкіри обличчя, білої лінії живота, шкіри навколо соска і наявність стрий на животі, стегнах можуть бути ознакою вагітності. Набряки на нижніх кінцівках та обличчі вказують на наявність гестозу.

5. Живіт. Велике значення має форма живота. Якщо вона овоїдна, необхідно визначити розташування овоїда (поперечне, повздовжнє або косе). Різко збільшений живіт кулеподібної форми спостерігається при багатоводді, відвислий чи загострений доверху живіт характерний для вузького таза. Втягнений пупок буває на ранніх термінах, згладжений - при вагітності 32-36 тиж., випуклий - при доношеній вагітності.

6. Стан молочних залоз. Розвиток молочних залоз, форма сосків, рубці вагітності, наявність виділень із сосків, наявність рубців після перенесеного маститу.

7. Дослідження внутрішніх органів. Серце, легені та органи черевної порожнини досліджуються за до- 
помогою пальпації, аускультації та перкусії. Проводиться огляд поперекової ділянки, перевіряється симптом Пастернацького. Відмічається наявність варикозного розширення підшкірних вен.

Спеціальне акушерське обстеження вагітної є складовою внутрішньопредметної інтеграції, свідчить про рівень засвоєння теоретичних знань та практичних навиків, зокрема щодо методів обстеження вагітної. Так, студенти проводять пельвіометрію, вимірюють обвід живота, висоту стояння дна матки та визначають передбачувану масу плода. Пальпацію проводять за допомогою чотирьох прийомів Леопольда, детально описуючи мету, методику проведення кожного прийому та висновок: положення плода, позиція, вид позиції, передлежання, рівень стояння передлеглої частини. Проводять аускультацію, тобто вислуховують серцебиття плода, встановлюють його локалізацію, звучність та ритмічність тонів, визначають їх частоту.

Під час огляду зовнішніх статевих органів звертають увагу на характер оволосіння, стан промежини, наявність варикозного розширення вен, кондилом, гемороїдальних вузлів, висипань, зовнішній отвір сечівника. Дослідження за допомогою дзеркал та піхвове дослідження студенти виконують на фантомах або спостерігають за виконанням їх викладачами чи практичними лікарями, що зумовлено правом вагітних жінок на відмову від огляду студентів. Проте студенти повинні вміти описати стан слизової оболонки стінок піхви (гіперемія, набряк) та характер виділень, стан шийки матки, а саме їі форму (циліндрична, конічна), форму зовнішнього вічка цервікального каналу (округла, щілиноподібна), колір слизової оболонки (ціаноз, гіперемія), наявність ерозій, розривів, виворотів, кондилом та дати оцінку. Знайомлячись 3 історією пологів, опрацьовуючи навчальні посібники, з допомогою викладача студенти також вчаться правильно описувати піхвове дослідження, зокрема стан піхви; стан шийки матки (довжина, консистенція, розміщення щодо провідної осі таза, розкриття цервікального каналу, стан нижнього сегмента). Особливі труднощі виникають у студентів при описі стану шийки матки під час пологів (згладжування, розкриття, товщина, наявність плодового міхура, рівень стояння передлеглої частини щодо площин малого таза).

При обгрунтуванні попереднього клінічного діагнозу зазначають показники, на основі яких він встановлений (скарги, анамнестичні дані та результати об'єктивного обстеження), вказують результати лабораторних, інструментальних та інших спеціальних методів обстеження. Так, акушерський клінічний діагноз містить такі складові:
1. Яка вагітність за рахунком.

2. Термін вагітності в тижнях.

3. Які роди за рахунком та період родів (у пологах).

4. Відходження навколоплодових вод (передчасне, раннє, вчасне, запізніле).

5. Положення, позиція, вид, передлежання плода.

6. Чи живий плід.

7. Розміри плода (гіпотрофія, великий плід, нормальних розмірів).

8. Одноплідна чи багатоплідна вагітність.

9. Який таз (нормальний, патологічний).

Після встановлення клінічного діагнозу студенти складають план ведення вагітності та пологів. Однією з відмінностей у написанні історії пологів є відсутність необхідності в проведенні дифдіагнозу.

Особливе місце в історії пологів та в об'єктивній оцінці знань студентів займає клінічний опис перебігу пологів. Студенти детально наводять дані про перебіг трьох періодів пологів із зазначенням часових характеристик, описують об'єктивний стан роділлі, скарги, відображають розвиток пологової діяльності, просування голівки по родовому каналу та стан плода, наводять дані про крововтрату та сучасні методи профілактики кровотечі, зокрема активне ведення третього періоду пологів. При проведенні оперативного втручання (кесарів розтин, ручне відділення та видалення посліду, ручна ревізія порожнини матки та ін.) слід написати показання, умови та хід виконання вказаної операції.

За час написання історії пологів студенти мають змогу, як мінімум, двічі відвідати куровану ними вагітну і описати перебіг післяпологового періоду у відповідному щоденнику, а стан новонародженого відобразити в щоденнику його розвитку.

Короткий опис історії пологів, оперативних втручань, післяпологового періоду, рекомендації при виписці додому по режиму породіллі та дитини відображають в епікризі.

До типових студентських помилок при написанні історії пологів можна віднести неправильне визначення тривалості періодів пологів та своєчасності відходження навколоплідних вод, неточності при описуванні огляду в дзеркалах та вагінального обстеження. Досить часто студенти допускають помилки при виписуванні рецептів лікарських засобів, зокрема неправильно визначають дозу, не вказують необхідність проведення проби на чутливість до антибіотиків, місцевих анестетиків.

Окремі студенти з особливою відповідальністю підходять до написання навчальної історії пологів, поглиблено вивчаючи предмет, працюючи 3 додат- 
ковою літературою, сучасними інформаційними джерелами. Власне цей етап самостійної підготовки студентів $€$ найбільш цінним, характеризує творчі та професійні здібності студента. Заповнення партограми не $€$ обов' язковою вимогою при написанні історії пологів, а виконується за бажанням студентів. Правильне заповнення партограми дає додаткові бали при оцінюванні викладача.

На написання навчальної історії пологів студентам відводиться календарний місяць. За цей час студенти мають змогу повторно відвідувати вагітну та породіллю, бути присутніми на пологах, звернутись до викладача за консультацією, опрацювати додаткову літературу та остаточно завершити написання історії пологів. Вкінці відведеного часу здійснюється перевірка написаної навчальної історії хвороби викладачем та надаються студентом-автором обгрунтовані відповіді

\section{Література}

1. Романенко Ю. В. Дидактичні технології викладання питань репродуктивного здоров'я : навчально-методичний посібник для викладачів / Ю. В. Романенко, А. І. Бойко, Н. Г. Гойда. - К. : Книга плюс, 2011. - 192 с.

2. Про схвалення Концепції Державної програми розвитку освіти на 2006 - 2010 роки : Розпорядження Кабінету Міністрів України № 396-р від 12.07.06. на зауваження та запитання стосовно змісту, тобто проходить захист історії пологів. Студент отримує дві оцінки за “історію пологів", одну - за письмову роботу, другу - за іï захист. Обидві оцінки впливають на загальну суму балів за перший модуль 3 акушерства.

Висновки: 1. Написання навчальної історії пологів дає можливість студенту реалізувати активне сприйняття навчального матеріалу під час навчальних занять, допомагає поглибити та закріпити набуті знання, розвиває аналітичний та системний підхід до проблемних питань дисципліни.

2. На всіх етапах написання історії пологів студент має можливість реалізувати свої творчі задатки та показати рівень засвоєння професійних знань.

3. Історія пологів, як вид самостійної роботи студента, й надалі $є$ ефективним елементом у процесі вивчення акушерства.

3. Вища освіта України і Болонський процес : навчальний посібник / [М. Ф. Степко, Я. Я. Болюбаш, В. Д. Шинкарук та ін.] ; за редакцією В. Г. Кременя. - Тернопіль : ВЕЖА, 2004. - 243 c.

4. Мілерян В. С. Методичні основи підготовки та проведення практичних занять в медичних вузах (методичний посібник) / В. С. Мілерян. -К. : Хрещатик, 2004. - 80 с. 